\title{
The Impact of IFRS on the Value Relevance of Accounting Information: Evidence from Turkish Firms
}

\author{
Sibel Karğ $1 n^{1}$ \\ ${ }^{1}$ School of Business Administration, Celal Bayar University, Manisa, Turkey \\ Correspondence: Sibel Karğın, School of Business Administration, Celal Bayar University, Manisa, Turkey. Tel: \\ 90-236-233-0657. E-mail: karginsibel@yahoo.com
}

Received: February 25, 2013

Accepted: March 11, $2013 \quad$ Online Published: March 18, 2013

doi:10.5539/ijef.v5n4p71

URL: http://dx.doi.org/10.5539/ijef.v5n4p71

\begin{abstract}
Value relevance is being defined as the ability of information disclosed by financial statements to capture and summarize firm value. Value relevance can be measured through the statistical relations between information presented by financial statements and stock market values or returns. In many studies, Ohlson model (1995) has been adopted to explore relationships among the market value of equity and two main financial reporting variables, namely the book value of equity per share (represents balance sheet) and earnings per share (represents income statement). This study investigates the value relevance of accounting information in pre- and post-financial periods of International Financial Reporting Standards' (IFRS) application for Turkish listed firms from 1998 to 2011. Market value is related to book value and earnings per share by using the Ohlson model (1995). Overall book value is value relevant in determining market value or stock prices. The results show that value relevance of accounting information has improved in the post-IFRS period (2005-2011) considering book values while improvements have not been observed in value relevance of earnings.
\end{abstract}

Keywords: value relevance, accounting information, IFRS, Ohlson model, ISE

\section{Introduction}

In this study, we explore the impact of International Financial Reporting Standards' (IFRS) adoption on the relevance of book value and earnings for stock valuation in Istanbul Stock Exchange (ISE). Turkey has mandated listed companies in ISE to use IFRS since 2005. International integration and growing economy force Turkish firms to use international standards in accounting and auditing to be integrated to the international environment. Reporting financial information in terms of international accounting standards could ease economic and financial integration because the most important issue for decision makers all over the world is to receive better financial information from financial reports.

Accounting information contained in financial statements is expected to be useful for decision makers. In order to provide this, financial statements should meet some basic characteristics. "If financial information is to be useful, it must be relevant and faithfully represent what it purports to represent. The usefulness of financial information is enhanced if it is comparable, verifiable, timely and understandable" (Conceptual Framework, 2010: A33).

Basic qualitative characteristics of financial statements are relevance and faithful presentation. "Relevant financial information is capable of making a difference in the decisions made by users. Information may be capable of making a difference in a decision even if some users choose not to take advantage of it or are already aware of it from other sources" (Conceptual Framework, 2010: A33). Besides relevance, financial information is needed to be presented faithfully. "To be useful, financial information must not only represent relevant phenomena, but it must also faithfully represent the phenomena that it purports to represent. To be a perfectly faithful representation, a depiction would have three characteristics. It would be complete, neutral and free from error. Of course, perfection is seldom, if ever, achievable" (Conceptual Framework, 2010: A34).

The existing literature presents contradicting results about whether the value relevance of accounting information has decreased or increased over time. Recent empirical studies have revealed that value relevance of accounting information has declined over the past few decades (Khanagha, 2011; Perera \& Thrikawala, 2010). Core et al. (2001) claim that the U.S.A. entered to a New Economy Period and traditional financial variables do not affect 
firm value in that period. They tested this claim for the period 1975-1999 and concluded that the ability of traditional financial variables to explain firm value decreased. Marquardt and Wiedman (2004) investigated the effect of earnings management on the value relevance of net income and book value in determining equity values. They observed a decline in value relevance of net income and they also found that when relevance of net income is low, book value has a greater effect in determining stock prices.

There is a need for evaluating whether implementing IFRS has improved value relevance of accounting information in Turkey since the financial statements have been presented in accordance with IFRS for almost 8 years. This study investigates the value relevance of accounting information in pre- and post-financial periods of International Financial Reporting Standards' (IFRS) application for Turkish listed firms from 1998 to 2011. As focusing on pre- and post-IFRS periods, this study aims to explore value relevance of book value and earnings per share to assess stock prices especially in post-IFRS periods. Using the Ohlson model (1995), market value is related to book value of equity per share and earnings per share. The results indicate that overall book value is value relevant in determining market value or stock prices and value relevance of accounting information has improved in the post-IFRS periods (2005-2011).

\subsection{Turkish Accounting System and IFRS}

Turkish government has played a key role in establishing and developing an accounting system through its bodies. Turkish accounting regulations, most applications, and rules were taken from the countries with which Turkey has both political and economic relationships. Related to the accounting applications, France and Germany have played an important role. From 1950s onwards, as a result of increasing relationships with the U.S.A., the Turkish Accounting System has been affected by US accounting practices. After 1987, with the application for EU membership, International Accounting Standards together with EU regulations and the rapid globalization movements around the world affected the Turkish Accounting System (Toraman \& Bayramnoğlu, 2006: 235).

IFRS have been developed by the International Accounting Standards Board, accepted by more than 100 countries around the world, and required for different types of companies. With the growth of economies and an increase in the number of publicly traded companies, Capital Markets Board of Turkey (CMB) has required publicly traded companies to apply IFRS starting with January 1 ${ }^{\text {st }}, 2005$ (Suadiye, 2012: 301). Prior to 2005, Turkish firms were using Turkish Uniform Accounting System (Turkish GAAP) that was legislated in 1994. Karapinar et al. (2006) state that the development of accounting standards dates back to 1980s and first accounting standard presented by the CMB dated January 29, 1989 under the title of "Serial: XI, No: 1 - The Communiqué for the Rules and Principles Pertinent to Financial Statements and Reports in the Capital Markets".

Within the bounds of Turkey's economic development, the CMB was established in 1981 by the Capital Markets Law No: 2499 next to banking which is the traditional financing system (Marşap \& Akbulut, 2006: 7). The regulatory and supervisory authority of securities markets and institutions in Turkey is the CMB. It regulates principles of capital markets and oversees the rights and interests of investors as well (TSPAKB, 2012: 3).

In Turkey, firms listed on ISE have been required to report their financial statements according to IFRS since 2005. Prior to that all required firms had to report their financial statements by Turkish GAAP.

\section{Literature Review}

Value relevance is being defined as the ability of information that is presented by financial statements to capture and summarize firm value. Value relevance can be measured by the statistical relations between information that financial statements present and stock market values or returns (Suadiye, 2012). Even though the concept is not new, the term "value relevance" was used by Amir et al. for the first time in 1993 in the related literature (Carnevale et al., 2009; Suadiye, 2012).

The value relevance of accounting information has been studied in many perspectives. Miller and Modigliani's (1966) study was one of the first studies investigating relations among accounting figures and other financial parameters. Miller and Modigliani (1966) investigated equity values that involved cost of capital in electric utility industry. The seminal article by Ball and Brown (1968) presented the relation between stock returns and earnings (Suadiye, 2012). As Ohlson (1991: 1) indicated "Without exaggeration, it can be said that the Ball-Brown (1968) paper has had an enormous influence on modern empirical accounting research. Their analysis has led to an informational perspective on accounting data". Ball and Brown (1968) related accounting income to stock prices. Besides Ball and Brown (1968) several researchers have examined the relation between stock prices or returns and accounting information. Ohlson model (1995) relates market value of a firm to accounting data (earnings, book values, and dividends). The model has been tested by many studies for many 
countries.

Ali and Hwang (2000) used accounting information of manufacturing firms in 16 countries for 1986-1995 and reported that the value relevance of financial reports is lower for countries where the financial systems are bank-oriented rather than market-oriented. Similar results were received for the countries where the private sector is not a part in the standard setting process and where tax rules have a greater impact on financial accounting measurements.

Cooke et al. (2009) examined the degree of long-run explanatory power of the book value of net assets for market value by investigating time series relations of five conglomerates in Japan for the period 1950-2004. Their results showed that in four of the five firms there is evidence of a long-run relationship between market value and the net book value of assets. Perera and Thrikawala (2010) found relations between market price per share and selected accounting information of commercial banks for 5 years in Sri Lanka. According to their findings, there is a relationship between accounting information and market price per share.

Al-Horani's (2010) study shows that both univariate and multivariate analyses present no evidence of value relevance of earnings components for aggregate banks as using commercial banks data for the period 2000-2008 in Amman Stock Exchange. Glezakos et al. (2012) related book value and earnings per share to share prices in Athens Stock Exchange for 38 firms. They presented that the value relevance of book value and earnings per share increased over time. Alali and Foote (2012) stated that earnings are positively related to cumulative returns and that earnings per share and book value per share are positively related to price per share in Abu Dhabi Stock Exchange.

\subsection{Previous Studies Related to Impact of IFRS on Value Relevance of Accounting Information}

Iatridis (2010) focuses on the effects of switching UK GAAP to IFRS in the UK. The results show that implementations of IFRS generally reinforce accounting quality and lead more value relevant accounting measures. However study of Papadatos and Bellas (2011) indicated that relation between mandatory implementation of IFRS and value relevance of accounting information may not be in the same direction for every firm since they stated that both firm size and fixed assets became significant factors in their study.

Dobija and Klimczak (2010) explored value relevance of accounting information in Polish market and found that market efficiency and value relevance did not noticeably improved after adoption of accounting standards while supporting harmonization process and foreign investment.

Khanagha (2011) examined the value relevance of accounting information in pre- and post-periods of IFRS implementation in United Arab Emirates (UAE). The results showed that accounting information is value relevant in UAE stock market in general but the value relevance of accounting data decreased with IFRS application. It is also stated that cash flows' incremental information content increased in the post-IFRS period.

Macías and Muiño (2011) examined accounting systems of countries some of which are full adopters and others are partial adopters of IFRS in Europe. They believed that accounting system serves the needs of capital providers in full adopter countries and it serves other purposes in partial adopter countries. Their results show that quality of accounting information improves with the full implementation of IFRS. Requiring the use of local standards in the preparation of legal entity financial statements presents lower level of accounting quality both prior to and after IFRS adoption. Macías and Muiño (2011) state that adoption of IFRS in these countries are mostly for satisfying regulatory needs and not for satisfying investors' and creditors' needs.

Van der Meulen et al. (2007) investigated the attribute differences (value relevance and timeliness) between US GAAP and IFRS earnings. They found that US GAAP and IFRS only differ with regard to the predictive ability as US GAAP outperforms IFRS in given controlling differences. However, they did not observe significant and consistent differences for the value relevance attribute. Verleun et al. (2011) investigated the impact of the Sarbanes-Oxley (SOX) Act on the quality of financial statements in U.S.A. for technology and non-technology firms. They presented evidence that the enactment of SOX has had a positive effect on accounting quality. They stated that the value relevance of accounting information has also increased after SOX was enacted.

Callao et al. (2007) focused on IBEX-35 companies to see the effects of the new standards on comparability and relevance of financial reporting in Spain. Their results show that local comparability is adversely affected if both IFRS and local accounting standards are used in the same country at the same financial period. Because of worsened local comparability, Callao et al. suggested an urgent transformation of local rules according to the international accounting standards. They also stated that even though value relevance of accounting information has not been significantly improved in the short run with the implementation of IFRS, it is expected to improve in the medium and long run. 
Karampinis and Hevas (2011) investigated IFRS implementation and value relevance of accounting data. They explored potential effects of IFRS implementation on two salient properties of accounting income; value relevance and conditional conservatism. Their results show that only minor improvements have been observed related with selected properties of income. Karampinis and Hevas (2009) found similar results for value relevance of mandatory application of IFRS in Greece. They concluded that mandating IFRS may be beneficial for the selected period. Study of Iatridis and Rouvolis (2010) also provided that IFRS adoption leads to more value relevant accounting measures in Greece Stock Exchange for 254 firms.

In Turkey value relevance of accounting information has also been analyzed in several perspectives. Kirkulak and Balsari (2009) analyzed the effect of inflation-adjusted data on explaining the market value of equity and stock returns in Turkey. They reported that both historical cost-based book value and earnings information and inflation-adjusted information are value relevant and they complement each other. Using them together results to more value relevance. However, they also stated that comparing value relevance of inflation-adjusted information is a unique opportunity since firms reported their financial statements in both historical cost numbers and inflation-adjusted numbers only for the year 2003. Because of lower inflation rates and the implementation of international accounting standards since 2005, applying inflation accounting would not be needed (Gücenme \& Poroy Arsoy, 2006).

Aktaş (2009) related data from balance sheet and income statement with the stock prices in Turkey. The study concluded that changes in net income, assets per share, book value per share, and liabilities per share are value relevant in calculating stock prices for the period of 1992-2007. Türel (2009) compared the value relevance of accounting information for the periods 2001-2002 and 2005-2006. The results showed that the value relevance of earnings and book value of equity has increased after adopting IFRS for the given period.

\section{Data and Methodology}

\subsection{Sample Selection and Data}

To test the value relevance of accounting information, our data covers the period from 1998 to 2011. The period is divided as pre-IFRS (1998-2004) and post-IFRS (2005-2011) periods to observe improvements on the value relevance of accounting information. Market Value per Share (MVPS) or stock prices, Book Value per Share (BVPS), and Earnings per Share (EPS) data was collected from Istanbul Stock Exchange (ISE) listed firms that implemented IFRS in 2005. Firms operating in financial sector were excluded from the sample due to different reporting requirements. Table 1's first column (column A) represents our initial sample that is not used in any regression models but used for detecting and excluding influential observations. The second sample is created as subtracting influential observations from initial sample (column B). The last sample contains firms that reported positive earnings (column C).

Table 1. Numbers of firms $1998-2011$

\begin{tabular}{lccc}
\hline Years & Initial Sample (A) & Initial Sample - Influential Observations (B) & Positive Earnings Reported (Positive EPS) (C) \\
\hline Pre-IFRS & & & 115 \\
1998 & 136 & 130 & 93 \\
1999 & 135 & 131 & 116 \\
2000 & 151 & 142 & 81 \\
2001 & 137 & 131 & 104 \\
2002 & 138 & 133 & 104 \\
2003 & 147 & 138 & 110 \\
2004 & 152 & 145 & 103 \\
Post-IFRS & & & 108 \\
2005 & 152 & 144 & 120 \\
2006 & 154 & 147 & 81 \\
2007 & 158 & 149 & 90 \\
2008 & 146 & 142 & 100 \\
2009 & 145 & 137 & 114 \\
2010 & 149 & 139 & \\
Pooled Data & 155 & 146 & 140 \\
\hline
\end{tabular}




\subsection{Methodology and Models}

Ohlson model (1995) is used for detecting value relevance of accounting data for the given period. The model is used to test our samples in four perspectives. The first one is to test value relevance of accounting data that does not contain influential observations (Table 1, column B). The second approach is to investigate the value relevance of accounting data for the firms that reported positive earnings (Table 1, column C). The third perspective is to test value relevance of pooled accounting data for the given time period and 1954 observations. And finally the Ohlson model (1995) is applied to see the improvements on the value relevance of accounting information in the pre- and post-IFRS periods.

A modified price model (Ohlson, 1995), which consists of two major indicators from financial reports (balance sheet and income statement), is used to test the value relevance of financial reporting in many studies. Ohlson model (1995) is adopted to explore relations between equity market value with two main financial reporting variables, namely the equity book value per share (represents balance sheet) and earnings per share (represents income statement). The equation of this econometric model is as follows (Kwong, 2010: 9-10):

$$
M V P S_{i t}=\alpha_{0}+\beta_{1} B V P S_{i t}+\beta_{2} E P S_{i t}+\varepsilon_{i t}
$$

where $M V P S_{i t}$ is the market value per share of firm i at time $\mathrm{t}$ (fiscal year-end), $B V P S_{i t}$ is the book value of equity per share of firm $i$ at year $t$, and $E P S_{i t}$ is the reported accounting earnings of firm $i$ at the fiscal year ended at time t.

In this study, the model (Model 1) is designed as market value per share (MVPS) or stock prices as dependent, book value per share $(B V P S)$ and accounting earnings per share $(E P S)$ as independent variables for the selected firms and the period of 1998-2011. Model 1 used data that do not include influential observations (Table 1, Column B).

Model 2 is used for pooled data that covers the time period of 1998-2011 for all firms and Model 3 is applied for testing firms that reported positive earnings.

Finally, Model 4 is designed to see the improvements of the value relevance of accounting data after IFRS implementation. $\beta_{3}$ and $\beta_{4}$ present the difference between coefficients of book value and earnings per share for the pre- and post-IFRS periods. If the difference of coefficients is positive (negative), that means the variable's value relevance increases (decreases) in the post-IFRS period. In order to detect changes in coefficients, pre- and post-IFRS dummy variables $(D)$ are used. " 0 " is used for pre-IFRS period (1998-2004) and "1" is for the post-IFRS. $\beta_{3}$ and $\beta_{4}$ are dummy variable coefficients of DBVPS and DEPS respectively.

Model 1. $M V P S_{i t}=\alpha_{0}+\beta_{1} B V P S_{i t}+\beta_{2} E P S_{i t}+\varepsilon_{i t}$

Model 2. $\quad$ MVPS $_{\text {it }}=\alpha_{0}+\beta_{1}$ BVPS $_{\text {it }}+\beta_{2}$ EPS $_{\text {it }}+\varepsilon_{\text {it }}$

Model 3. $\quad \mathrm{MVPS}_{\mathrm{it}}^{+}=\alpha_{0}^{+}+\beta_{1}^{+} \mathrm{BVPS}_{\mathrm{it}}^{+}+\beta_{2}^{+} \mathrm{EPS}_{\mathrm{it}}^{+}+\varepsilon_{\mathrm{it}}^{+}$

Model 4. $\quad$ MVPS $_{\text {it }}=\alpha_{0}+\alpha_{1} \mathrm{D}+\beta_{1} \mathrm{BVPS}_{\text {it }}+\beta_{2} \mathrm{EPS}_{\mathrm{it}}+\beta_{3} \mathrm{DBVPS}_{\mathrm{it}}+\beta_{4} \mathrm{DEPS}_{\mathrm{it}}+\varepsilon_{\mathrm{it}}$

\section{Results}

Table 2 presents the results of Model 1, yearly cross-sectional regressions of price on earnings and book value. Coefficient estimates are calculated based on Ordinary Least-Squares (OLS) estimation. The adjusted $R^{2}$ ranged from $25 \%$ in 2010 to $75 \%$ in 2004 for the yearly cross-sectional regressions of price on earnings and book value and the mean is $54 \%$. In each year the book value's coefficient estimates are significant and positive $(p<0.05)$. As it is presented in Table 2, $F$ test values are statistically significant in each year as well. Additionally coefficient estimates of earnings are positive in each year and statistically significant for the years of 1998, 1999, 2000, and 2007. Multicollinearity is evaluated by Variance inflation factors (VIF). VIF indicate that multicollinearity is not likely to be a serious problem. 
Table 2. Yearly cross-sectional regressions of price on earnings and book value

\begin{tabular}{|c|c|c|c|c|c|c|c|c|c|c|}
\hline \multirow[b]{2}{*}{ Years } & \multicolumn{10}{|c|}{$M V P S_{i t}=\alpha_{0}+\beta_{1} B V P S_{i t}+\beta_{2} E P S_{i t}+\varepsilon_{i t}$} \\
\hline & $\alpha_{0}$ & $\mathrm{p}^{\mathrm{a}}$ & $\beta_{1}$ & $\mathrm{p}^{\mathrm{a}}$ & $\beta_{2}$ & $\mathrm{p}^{\mathrm{a}}$ & $R^{2 \mathrm{~b}}$ & F-stat. & $\mathrm{p}^{\mathrm{a}}$ & $\mathrm{VIF}^{\mathrm{c}}$ \\
\hline 1998 & 0.9948 & 0.4067 & 1.2720 & 0.0006 & 5.3246 & 0.0000 & 0.6621 & 46.25 & 0.0000 & 1.8230 \\
\hline 1999 & 0.6597 & 0.7541 & 4.3335 & 0.0000 & 7.5911 & 0.0039 & 0.6346 & 33.18 & 0.0000 & 1.9060 \\
\hline 2000 & 0.9720 & 0.3035 & 1.1777 & 0.0000 & 4.1818 & 0.0064 & 0.5797 & 17.83 & 0.0000 & 2.6540 \\
\hline 2001 & 2.3716 & 0.0011 & 1.2801 & 0.0000 & 0.5390 & 0.3347 & 0.6693 & 76.19 & 0.0000 & 2.4930 \\
\hline 2002 & 1.9011 & 0.0000 & 0.8069 & 0.0000 & 0.2353 & 0.6886 & 0.6182 & 58.83 & 0.0000 & 1.6680 \\
\hline 2003 & 1.4526 & 0.0001 & 0.5907 & 0.0000 & 1.1191 & 0.2036 & 0.5678 & 23.45 & 0.0000 & 1.5570 \\
\hline 2004 & 0.7599 & 0.1633 & 0.7841 & 0.0025 & 2.2685 & 0.2781 & 0.7518 & 22.11 & 0.0000 & 2.9120 \\
\hline 2005 & -0.7138 & 0.7054 & 2.3125 & 0.0232 & -1.4830 & 0.7488 & 0.3935 & 72.24 & 0.0000 & 2.5230 \\
\hline 2006 & -0.3577 & 0.7827 & 2.0629 & 0.0212 & -1.6938 & 0.6475 & 0.4435 & 26.33 & 0.0000 & 3.6710 \\
\hline 2007 & 0.3692 & 0.6576 & 1.0295 & 0.0065 & 2.4258 & 0.0894 & 0.4596 & 12.83 & 0.0000 & 2.1100 \\
\hline 2008 & 0.7332 & 0.0660 & 0.7837 & 0.0000 & 0.4769 & 0.5210 & 0.6930 & 35.45 & 0.0000 & 1.9940 \\
\hline 2009 & 1.1564 & 0.5973 & 2.0499 & 0.0000 & -6.7340 & 0.2305 & 0.4441 & 39.95 & 0.0000 & 1.0070 \\
\hline 2010 & -0.7215 & 0.7957 & 3.0433 & 0.0163 & 2.6823 & 0.5541 & 0.2502 & 29.09 & 0.0000 & 1.3670 \\
\hline 2011 & -0.1100 & 0.9470 & 2.4494 & 0.0002 & 0.2319 & 0.9279 & 0.3480 & 14.03 & 0.0000 & 2.6210 \\
\hline
\end{tabular}

Notes: ${ }^{a}$ White's Heteroscedasticity-Consistent Variances and Standard Errors. Statistically significant if $p<0.1010 \%, p<0.055 \%$, and $p<0.01$ $1 \%$. ${ }^{b} \overline{\mathrm{R}}^{2}$ : Explanatory power of book value and earnings per share to market value per share. ${ }^{\mathrm{c}}$ VIF for Ohlson model. If VIF $>10$, it indicates multicollinearity.

The results of the pooled data presented in Table 3 - Panel I show that the coefficient estimates of both earnings and book value are positive. However, only book value has significant effect on the market value per share or stock prices. That means only book value is a significant accounting variable for selected ISE firms' stock valuation.

It can be said that book value and earnings per share jointly explain $38 \%$ of the cross-sectional variation in stock prices for the period of 1998-2011.

Variance inflation factor $(V I F)$ was also calculated and found to be within the acceptable limit (1.79) as presented in Table 3 because the VIF value is smaller than 10 .

The results of multiple linear regression of stock prices on book value and earnings for firms that reported positive earnings are presented in Table 3 - Panel II. The coefficient estimates of both book value and earnings per share have positive and significant $(p<0.01)$ effects on stock prices of selected ISE firms.

The coefficients of book value and earnings are about 1.00 and 6.02 for the firms that reported positive earnings with adjusted $R^{2}$ value of 0.47 . The results show that the earnings per share is a dominant valuation variable in the firms that reported positive earnings compared to book value.

Table 3. Pooled and positive earnings reported data: Cross-sectional regressions of book value and price on earnings

\begin{tabular}{|c|c|c|c|c|}
\hline & $M V P S_{i t}=\alpha_{0}+$ & $\begin{array}{l}\boldsymbol{I}^{\mathrm{a}} \\
+\beta_{2} E P S_{i t}+\varepsilon_{i t}\end{array}$ & \multicolumn{2}{|c|}{$\mathrm{MVPS}_{\mathrm{it}}^{+}=\alpha_{0}^{+}+\beta_{1}^{+} \mathrm{BVPS}_{\mathrm{it}}^{+}+\beta_{2}^{+} \mathrm{EPS}_{\mathrm{it}}^{+}+\varepsilon_{\mathrm{it}}^{+}$} \\
\hline & Coefficient & $p$ - value ${ }^{\mathrm{c}}$ & Coefficient & $p$ - value ${ }^{\mathrm{c}}$ \\
\hline$\alpha_{0}$ & 1.5715 & 0.0291 & 0.6191 & 0.5499 \\
\hline$\beta_{1}$ & 1.5903 & 0.0000 & 1.0018 & 0.0000 \\
\hline$\beta_{2}$ & 1.4970 & 0.1831 & 6.0246 & 0.0000 \\
\hline F-stat. & 51.8829 & 0.0000 & 41.8742 & 0.0000 \\
\hline $\bar{R}^{2 \mathrm{~d}}$ & \multicolumn{2}{|c|}{0.3886} & \multicolumn{2}{|c|}{0.4769} \\
\hline$V I F^{\mathrm{e}}$ & \multicolumn{2}{|c|}{1.7910} & \multicolumn{2}{|c|}{2.7080} \\
\hline
\end{tabular}

Notes: ${ }^{\text {a }}$ Ohlson model (1995) pooled sample results for the years of 1998-2011 period. ${ }^{b}$ Ohlson model (1995) results of pooled data for the firms reported positive earnings for the period of 1998-2011. ${ }^{\mathrm{c}}$ White's Heteroscedasticity-Consistent Variances and Standard Errors. Statistically significant if $p<0.1010 \%, p<0.055 \%$, and $p<0.011 \% .{ }^{\mathrm{d}} \overline{\mathrm{R}}^{2}$ : Explanatory power of book value and earnings per share to market value per share. ${ }^{\mathrm{e}} V I F$ for Ohlson model (1995). If $V I F>10$, it indicates multicollinearity. 
Regression results presented for each year in Table 2 consistently support the pooled data results in Table 3 Panel I. Table 2 and Table 3 reveal that book value is relevant in determining stock prices. The question is whether value relevance of accounting information has improved after the implementation of IFRS. In order to answer that question, pre- and post-IFRS implementation data is needed to be compared. Table 4 reveals that comparison.

The slope coefficients and related $p$-values, adjusted $R^{2}$, and $F$-statistics for pooled and positive earnings data are reported in Table 4. The slope coefficient of DBVPS is significant $(p<0.05)$ while the coefficient of DEPS is negative and insignificant. The adjusted $R^{2}$ of the model for pooled data is about 0.40 . In order to see the structural breaks in the model, Chow Test is applied for the pooled data and the data of the firms reporting positive earnings. Chow test is detected in certain range of $p$ values (if $p<0.1010 \%, p<0.011 \%$ the case of statistically significant structural break).

Coefficients of $\beta_{3}$ and $\beta_{4}$ present changes or improvement in value relevance of accounting information after IFRS for book value and earnings per share respectively. Positive coefficient means an increase in value relevance of accounting data, while the negative sign presents a decline. Based on that, it can be seen that value relevance of accounting information has increased significantly in the post-IFRS period for the book value of per share because the coefficient of book value increased by 0.9580 (as $\beta_{3}$ ) and the change is positive. However, this improvement has not been observed in value relevance of earnings per share since the value of earnings coefficient decreased by -2.7146 (as $\beta_{4}$ ) and the change is negative. It can be concluded that value relevance of accounting information decreased significantly in the post-IFRS period for earnings per share.

Table 4. The results of chow test for the pooled and positive earnings data

\begin{tabular}{|c|c|c|c|c|}
\hline & \multicolumn{2}{|c|}{ Panel I $^{\text {a }}$} & \multicolumn{2}{|c|}{ Panel II $^{\mathrm{b}}$} \\
\hline & Coefficient & $p$-value ${ }^{\mathrm{c}}$ & Coefficient & $p$-value $\mathrm{e}^{\mathrm{c}}$ \\
\hline$\alpha_{0}$ & 3.7712 & 0.0000 & 3.6176 & 0.0000 \\
\hline$\beta_{1}$ & 0.9986 & 0.0003 & 0.0939 & 0.5825 \\
\hline$\beta_{2}$ & 2.9144 & 0.0234 & 8.0338 & 0.0000 \\
\hline$\beta_{3}$ & 0.9580 & 0.0216 & 1.6992 & 0.0000 \\
\hline$\beta_{4}$ & -2.7146 & 0.2261 & -4.6375 & 0.0441 \\
\hline$F-$ stat $^{\mathrm{d}}$ & 2.3775 & 0.0681 & 5.7306 & 0.0007 \\
\hline $\bar{R}^{2}$ & \multicolumn{2}{|c|}{0.4029} & \multicolumn{2}{|c|}{0.5145} \\
\hline \multicolumn{5}{|c|}{$\begin{array}{l}\text { Notes: }{ }^{\mathrm{a}} M V P S_{i t}=\alpha_{0}+\alpha_{1} D+\beta_{1} B V P S_{i t}+\beta_{2} E P S_{i t}+\beta_{3} D B V P S_{i t}+\beta_{4} D E P S_{i t}+\varepsilon_{i t} \cdot{ }^{\mathrm{b}} M V P S_{i t}^{+}=\alpha_{0}^{+}+\alpha_{1}^{+} D+\beta_{1}^{+} B V P S_{i t}^{+}+\beta_{2}^{+} E P S_{i t}^{+}+ \\
\beta_{3} D B V P S_{i t}^{+}+\beta_{4} D E P S_{i t}^{+}+\varepsilon_{i t}^{+} .{ }^{\mathrm{c}} \text { White's Heteroscedasticity-Consistent Variances and Standard Errors. Statistically significant if } p<0.1010 \% \text {, } \\
p<0.055 \% \text {, and } \mathrm{p}<0.011 \% .{ }^{\mathrm{d}} \text { For Panel I F (3.2015), for Panel II F (3.144) Chow test for the presence of a structural break, if } p<0.1010 \% \text {, } \\
p<0.011 \% \text { the case of statistically significant structural break. }\end{array}$} \\
\hline
\end{tabular}

As Table 4 and Table 3 have been compared, it can be seen that the results of the firms reported positive earnings in Table 3 - Panel II and the results of pooled data are consistent with each other. Coefficient estimation of $\beta_{3}$ is positive while coefficient of $\beta_{4}$ is negative and the values are statistically significant. The results can be interpreted as that value relevance of book value per share has increased after implementation of IFRS for the selected firms of ISE. Since Chow test is 5.73 at the $1 \%$ level, change of value relevance of accounting information is statistically significant. However, value relevance of earnings per share has decreased in post-IFRS period for the selected firms of ISE.

\section{Concluding Remarks and Suggestions for Further Future Research}

International Financial Reporting Standards (IFRS) have been developed by the International Accounting Standards Board, accepted by more than 100 counties around the world, and required for different types of companies. With the growth of economies and numbers of publicly traded companies, Capital Markets Board of Turkey (CMB) required public companies to apply IFRS for fiscal years starting on or after 1 January 2005.

The value relevance of accounting information has been studied in many perspectives. Literature has offered contradicting results about whether relevance of accounting information has declined or increased over time. Although some recent empirical studies reveal that value relevance of accounting information declines, literature contains many studies revealing that value relevance of accounting numbers increases. Many countries' results show that adopted IFRS significantly improve value relevance of accounting information. This study is consistent with the studies that reveal an increase in the value relevance of accounting information after implementation of IFRS. 
In many studies Ohlson model (1995) has been adopted to explore relations between equity market value with two main financial reporting variables, namely the equity book value per share (represents balance sheet) and earnings per share (represents income statement).

This study investigates the value relevance of accounting information in pre- and post- financial periods of International Financial Reporting Standards (IFRS) applications for Turkish listed firms from 1998 to 2011. Market value is related to book value and earnings per share by using the Ohlson model (1995). Overall book value is value relevant in determining market value or stock prices. The results show that value relevance of accounting information has improved in the post-IFRS period (2005-2011) considering book values while an improvement has not been observed in value relevance of earnings.

Results of pooled data and firms that report positive earnings show that book value is value relevant in determining stock prices for the selected firms and years. Reviewing value relevance of book value, improvements have not been observed in earnings.

IFRS have improved value relevance of accounting information in Turkey for the selected firms and periods. This result may be caused that IFRS applications, i.e. fair value presentation of financial reports, would lead to a closer book and market values.

\section{References}

Aktaş, H. (2009). Hisse Senetleri Piyasasında Muhasebe Bilgilerinin Önemi: IMKB'de Değer İlişkisi Analizi. Ankara: Gazi Kitabevi. (Magnitude of Accounting Information in Stock Markets: Value Relevance Analysis. Ankara: Gazi Press).

Alali, F. A., \& Foote, P. S. (2012). The Value Relevance of International Financial Reporting Standards: Empirical Evidence in an Emerging Market. The International Journal of Accounting, 47, 85-108. http://dx.doi.org/10.1016/j.intacc.2011.12.005

Al-Horani, A. M. (2010). Testing the Relationship between Abnormal Returns and Non-Interest Earnings: The Case of Jordanian Commercial Banks. International Research Journal of Finance and Economics, 55, 108-117.

Ali, A., \& Hwang, L. S. (2000). Country-Specific Factors Related to Financial Reporting and the Value Relevance of Accounting Data. Journal of Accounting Research, 38(1), 1-21. http://dx.doi.org/10.2307/2672920

Amir, E., Harris, T., \& Venuti, E. (1993). A Comparison of the Value-Relevance of US versus Non-US GAAP Accounting Measures Using Form 20F Reconciliations. Journal of Accounting Research, 31, 230-264. http://dx.doi.org/10.2307/2491172

Ball, R., \& Brown, P. (1968). An Empirical Evaluation of Accounting Income Numbers. Journal of Accounting Research, 6(2), 159-178. http://dx.doi.org/10.2307/2490232

Callao, S., Jarne, J. I., \& Laínez, J. A. (2007). Adoption of IFRS in Spain: Effect on the Comparability and Relevance of Financial Reporting. Journal of International Accounting, Auditing and Taxation, 16, 148-178. http://dx.doi.org/10.1016/j.intaccaudtax.2007.06.002

Carnevale, C., Giunta, F., \& Cardamone, P. (2009). The Value Relevance of Social Report. The European Financial Management Association. Retrieved from http://www.efmaefm.org/0EFMAMEETINGS/EFMA\%20ANNUAL\%20MEETINGS/2009-milan/EFMA2 009_0722_FullPaper.pdf

Conceptual Framework for Financial Reporting. (2010). September.

Cooke, T., Omura, T., \& Willett, R. (2009). Consistency, Value Relevance and Sufficiency of Book for Market Values in Five Japanese Conglomerates over the Period 1950-2004. Abacus, 45(1), 88-123. http://dx.doi.org/10.1111/j.1467-6281.2009.00279.x

Core, J. E., Guay, W. R., \& Van Buskirk, A. (2001). Market Valuations in the New Economy: An Investigation of What has Changed. JAE Boston Conference, June 2001. http://dx.doi.org/10.2139/ssrn.262619

Dobija, D., \& Klimczak, K. M. (2010). Development of Accounting in Poland: Market Efficiency and the Value Relevance of Reported Earnings. The International Journal of Accounting, 45, 356-374. http://dx.doi.org/10.1016/j.intacc.2010.06.010

Glezakos, M., Mylonakis, J., \& Kafouros, C. (2012). The Impact of Accounting Information on Stock Prices: Evidence from the Athens Stock Exchange. International Journal of Economics and Finance, 4(2), 56-68. 
http://dx.doi.org/10.5539/ijef.v4n2p56

Gücenme, Ü., \& Poroy Arsoy, A. (2006). Changes in Financial Reporting in Turkey: Historical Development of Inflation Accounting from 1960 to 2005. Eleventh World Congress of Accounting Historians, Nantes, (France), July 19-22, Papers of Turkish Delegation. Retrieved from http:/journal.mufad.org/attachments/article/204/a5-changes_in_financial_reporting_in_turkey.pdf

Iatridis, G. (2010). International Financial Reporting Standards and the Quality of Financial Statement Information. International Review of Financial Analysis, 19, 193-204. http://dx.doi.org/10.1016/j.irfa.2010.02.004

Iatridis, G., \& Rouvolis, S. (2010). The Post-Adoption Effects of the Implementation of International Financial Reporting Standards in Greece. Journal of International Accounting, Auditing and Taxation, 19, 55-65. http://dx.doi.org/10.1016/j.intaccaudtax.2009.12.004

Karampinis, N. I., \& Hevas, D. L. (2009). The Effect of the Mandatory Application of IFRS on the Value Relevance of Accounting Data: Some Evidence from Greece. European Research Studies, 12(1), 73-100.

Karampinis, N. I., \& Hevas, D. L. (2011). Mandating IFRS in an Unfavorable Environment: The Greek $\begin{array}{llll}\text { Experience. The International Journal of Accounting, 46, 304-332. } & \text { The }\end{array}$ http://dx.doi.org/10.1016/j.intacc.2011.07.001

Karapınar, A., Zaif Ayıkoğlu, F., \& Bayırlı, R. (2006). Convergence and Harmonization with International Financial Reporting Standards: A Perspective of Turkey. Eleventh World Congress of Accounting Historians. Nantes, (France), July 19-22, Papers of Turkish Delegation. Retrieved from http://journal.mufad.org/attachments/article/465/22.pdf

Khanagha, J. B. (2011). Value Relevance of Accounting Information in the United Arab Emirates. International Journal of Economics and Financial Issues, 1(2), 33-45.

Kirkulak, B., \& Balsari, C. K. (2009). Value Relevance of Inflation-Adjusted Equity and Income. The International Journal of Accounting, 44, 363-377. http://dx.doi.org/10.1016/j.intacc.2009.09.007

Kwong, L. C. (2010). The Value Relevance of Financial Reporting in Malaysia: Evidence from Three Different Financial Reporting Periods. International Journal of Business and Accountancy, 1(1), 1-19.

Macías, M., \& Muiño, F. (2011). Examining Dual Accounting Systems in Europe. The International Journal of Accounting, 46, 51-78. http://dx.doi.org/10.1016/j.intacc.2010.12.001

Marquardt, C. A., \& Wiedman, C. I. (2004). The Effect of Earnings Management on the Value Relevance of Accounting Information. Journal of Business Finance \& Accounting, 31(3\&4), 297-332. http://dx.doi.org/10.1111/j.0306-686X.2004.00541.x

Marşap, B., \& Akbulut, Y. (2006). The Effects of the Uniform Accounting System Studies and the Development of Tax Regulations on Accounting Applications during the Period of the Turkish Republic (1923-2006). Eleventh World Congress of Accounting Historians, Nantes, (France), July 19-22, Papers of Turkish Delegation. Retrieved from http://journal.mufad.org/attachments/article/462/19.pdf

Miller, M. H., \& Modigliani, F. (1966). Some Estimates of the Cost of Capital to the Electric Utility Industry, 1954-57. The American Economic Review, 56(3), 333-391.

Ohlson, J. A. (1991). The Theory of Value and Earnings, and an Introduction to the Ball-Brown Analysis. Contemporary Accounting Research, 8(1), 1-19. http://dx.doi.org/10.1111/j.1911-3846.1991.tb00831.x

Ohlson, J. A. (1995). Earnings, Book Values, and Dividends in Equity Valuation. Contemporary Accounting Research, 11(2), 661-687. http://dx.doi.org/10.1111/j.1911-3846.1995.tb00461.x

Papadatos, K., \& Bellas, A. (2011). The Value Relevance of Accounting Information under Greek and International Financial Reporting Standards: The Influence of Firm-Specific Characteristics. International Research Journal of Finance and Economics, 76, 6-23.

Perera, R. A. A. S., \& Thrikawala, S. S. (2010). An Empirical Study of the Relevance of Accounting Information on Investor's Decisions. University of Kelaniya, Kelaniya, Sri Lanka. Retrieved from http://repository.kln.ac.lk/91/1/FIN002.pdf

Suadiye, G. (2012). Value Relevance of Book Value \& Earnings under the Local GAAP and IFRS: Evidence from Turkey. Ege Akademik Review, 12(3), 301-310.

Suadiye, G. (2012). Value Relevance of Book Value \& Earnings under the local GAAP and IFRS: Evidence from 
Turkey. Ege Akademik Review, 12(3), 301-310.

Toraman, C., \& Bayramoğlu, F. (2006). Effects of the Adoption of European Union Standards on Accounting Practices. Mali Çözüm Dergisi, 76, 220-241.

TSPAKB. (2012). The Association of Capital Market Intermediary Institutions of Turkey. The handbook of the Turkish capital markets 2012. Retrieved from http://www.tspakb.org.tr/eng/Portals/57ad7180-c5e7-49f5-b282-c6475cdb7ee7/AIM_Publication_the_hand book_of_TCM_2012.pdf

Türel, A. (2009). The Value Relevance of IFRS: The Case of Turkey. Acta Universitatis Danubius. Economica, $5(1), 119-128$.

Van der Meulen, S., Gaeremynck, A., \& Willekens, M. (2007). Attribute Differences between U.S. GAAP and IFRS Earnings: An Exploratory Study. The International Journal of Accounting, 42(2), 123-142. http://dx.doi.org/10.1016/j.intacc.2007.04.001

Verleun, M., Georgakopoulos, G., Sotiropoulos, I., \& Vasileiou, K. Z. (2011). The Sarbanes-Oxley Act and Accounting Quality: A Comprehensive Examination. International Journal of Economics and Finance, 3(5), 49-64. http://dx.doi.org/10.5539/ijef.v3n5p49 